\title{
EU and International Income Tax Coordination After the Pandemics: It Is Time to Take It Personal
}

In troubled times, focus should be on essentials, and tax policy is no exception. What the world has endured in the last year and a half has shaken the foundations of our social life. In many countries, prolonged lockdowns have not only strained the economy, they have taken a heavy toll on psychological welfare and human relationships in an unprecedented way.

During this time, much of the international tax debate has focused on macropolitical issues such as new sources of financing for budgets running in deficit, taxation on multinational companies, and tax instruments to mitigate climate change. Those are worthy objectives, and progress that has been made should certainly be welcomed. However, minimal attention has been paid to the tax rules that most deeply affect taxpayers' everyday lives. Personal income taxes fall directly on working parents having to take care of children because of theocons of schools; self-employed running small businesses such as hairdressers, restaurants, fitness centres, or theatres who have been locked down by governmental decisions; workers from large plants who have been laid off or furloughed due to a fall of demand for the products they used to manufacture; employees living alone who have been remotely working from home for months without any social contacts. Besides introducing temporary suspension of tax debt - mostly for the self-employed - states have not yet seized the opportunity to use the personal income tax as a tool to support, heal, and boost these citizens on the path to recovery.

The history of personal income taxes is deeply intertwined with the evolution of democracy and social emancipation. The beginning of the twentieth century saw the parallel introduction of universal (male) suffrage and the appearance of global personal (real) income tax. These two revolutions contributed in a decisive way to transform the role of the state from the guardian of the privileges of a minority to the authority in charge of preserving the good of the greater number. This was made possible because, on the one hand, a larger part of the population was represented in the legislative bodies responsible for determining the scope and role of public authorities. On the other hand, considerable financial resources could be invested in redistribution and welfare. This trend was further amplified in the middle of the twentieth century with the appearance of social security contributions and VAT that helped finance ambitious policies in the field of healthcare, education, and social protection.

However, it is no secret that personal income tax is in a crisis that is associated with several causes.

Within today's societies, diverse and individualistic, to implement a single 'one-size-fits-all' tax system is made increasingly complex. At the same time, the polarization of the political debate in many countries has made it very difficult to adopt fundamental reforms, often leaving obsolete tax systems in force that were designed for a totally different economic, social, and technological context. In addition, an entire series of specific measures (many of them were supposed to be temporary) have gradually been added to the system, further weakening its coherence and legibility.

Moreover, personal income tax has always been a battleground for the most diverse lobbies in order to gain or to maintain preferential regimes that were often disguised as general interest measures. ${ }^{1}$ Governments are faced with systematic and pressing demands to adopt ad hoc tax regimes. This is particularly the case of measures aiming at reducing the effective tax rate of the wealthiest individuals while low and middle wage earners have not seen similar reductions in their tax burden. At the same time, in the European Union and also in the United States in the last decades, real wages have stagnated and social benefits and public financing of public services have also eroded.

\section{Notes}


Globalization, on the other hand, multiplied cross-border situations and the obligation to take into account in each of the particular rules the fact that it could apply to taxpayers or transactions totally or partially located outside the territorial sphere of application of the tax system in question. This is also very much reflected in the European Union by the obligation to adapt legislation to the evolution of supranational case law on freedom of movement. This sometimes occurs at the expense of the internal coherence of the domestic tax system, which has been rarely accepted by the European Court of justice. ${ }^{2}$

At the same time, the high mobility of taxpayers, especially the wealthiest combined with a very active and effective lobbying against (progressive) taxation has pushed marginal tax rates down, and tailor-made preferential tax regimes - whether for pensioners, artists and sportsmen, or corporate executives - have rapidly expanded mushroomed.

Finally, the systematic tendency to use tax credits and tax allowances to encourage non-tax sectoral policies has led to the introduction of exogenous grafts into the income tax system, often at costs excessive in relation to the results. This is not only a problem of poor policy design but also because compliance with conditions (if any) related to their applications are left to the discretion of the tax authorities - who lack the technical competence - and human resources to ensure the correct application of measures far beyond their file of expertise such as environmental tax credits or tax reductions for investment in long-term savings financial instruments.

Examining this grim scenario, increased focus on personal taxation at the international and European levels could certainly elucidate the national tax debate and ensure that personal income tax systems fulfil their role as essential tools of human development in a post-pandemic world. As the European tax harmonization phenomenon demonstrates, in particular regarding reduced VAT rates and exemptions, international coordination may help national governments to resist inappropriate pressures and to implement policies that are more fair and efficient.

There is however no need to push for a full-fledged uniformization of personal income tax at the European (or international) level. That is politically unfeasible but also not necessarily desirable. Pushing states to converge regarding the overall tax pressure on personal income would necessitate creating macro redistribution mechanisms (intergovernmental grants, central social security, etc.) similar to those existing in federal states. Without those mechanisms, (upward) harmonization of personal income taxes would primarily benefit high-taxing, richer countries and, in this context, must be considered as a luxury that a less financially advantaged country cannot afford. High tax rates imply a rather high level of disposable income for average taxpayers and a relatively high output of public services in order to avoid phenomenon such as tax emigration by wealthier taxpayers and social resistance or even unrest by those who remain. Moreover, even if a correlation between state building and an increase in redistribution through taxation may be established in some cases, comprehensive reform of the tax system based on an internationally-agreed model is not a guarantee for development that is the result of a variety of country-related historical, political, and economic factors. ${ }^{3}$

For the longer term, however, promoting international financial solidarity flowing from supranational taxes - especially at the regional level like in the European Union - should remain a political objective in order to approximate living conditions among populations. This is not only based on moral considerations but also because it helps solving extremely controversial issues such as mass immigration, international conflicts, and systematic economic exploitation

For now, better coordination should be the aim at European and international levels on - at least - three areas of personal income taxation: harmful tax competition and double taxation; tax incentives; and taxpayers' rights.

Harmful tax competition has, for a long time, been associated with preferential corporate tax regimes adopted by states in order to foster investment or retain economic activities by multinational groups on the territory. Due to the notably difficult work of international organizations such as the OECD and the EU, there is now better coordination even though there is much yet to be accomplished. For example, despite the efforts made, there has never been as many free trade zones in the world as there is currently. ${ }^{4}$

It can be observed that an increasing number of states are implementing favourable regimes to attract not only companies but individuals. Whether under the form of tax holidays, exemption for foreign income, or generous deductions for real or deemed expatriation costs, wealthy taxpayers are courted by governments that are eager to expand their personal income tax base. Within the EU, of course, this is a game that ultimately results in an overall loss of revenue. Moreover, besides the significant portion

\section{Notes}

2 F. Vanistendael, The Functioning of Fundamental Freedoms and Tax Neutrality in the Internal Market, in Research Handbook on European Union Taxation Law 142 (C. H. J. I. Panayi, W. Haslehner \& E. Traversa eds, Edward Elgar Publishing 2020).

3 See M. Keen, Taxation and Development - Again IMF Working Paper No. 12/220. (Sept. 2012). T. Besley \& T. Persson, Why Do Developing Countries Tax So Little?, 28(4) J. Econ. Persp. 99-12 (2014)

4 According to the UNCTAD, there are currently more than 5,000 Free Zones in the world. See UNCTAD, World Investment Report 2019, Special Economic Zones (2019), https:// unctad.org/system/files/official-document/wir2019_en.pdf (accessed 8 Feb. 2021). 
of taxes that are forfeited, the multiplication of favourable tax regimes undermine the legitimacy of progressive income taxes and equality before the (tax) law. More international tax coordination is needed and should take the form of a code of conduct (with peer review mechanisms and black listing) as well as the generalization of exit and trailing taxes to ensure that taxes are paid at least somewhere. Existing mechanisms for exchanging information about individuals could be extended to cover not only the type of income but also its tax treatment in the jurisdiction transmitting the information. This would allow the state of residence to adjust the application of its taxes to the actual situation in the state of source thus preventing any risk of non-taxation but also avoid, in most cases, a situation of double taxation. Indeed, following the example of what is currently discussed at the OECD level in the field of corporate tax, a minimum tax threshold could be agreed upon above which an exemption from tax in the state of residence (subject to progressivity clause) would be automatically granted to taxpayers. Otherwise, a tax credit would be granted.

It is worth noting that the EU Commission has proposed to extend the scope of the code of conduct for business taxation to 'citizenship schemes or measures to attract expatriates or wealthy individuals, ${ }^{, 5}$ and has announced an initiative to ensure 'a more consistent determination of tax residence within the Single Market'. 6 Those are certainly welcome initiatives that could lead to further steps towards increased coordination in the field of personal taxation.

Another area where international and EU coordination would be welcome is the identification and monitoring of (domestic) tax incentives. The experience of previous crises, notably the subprime scandal in the United States, show how excessive household indebtedness could have extremely damaging consequences on the global financial system. Such a finding pleads in favour of the reduction of phasing out of tax incentives regarding mortgage deductions. For the same reasons, rules leading to preferential tax treatment for financial instruments such as derivatives or stock options, whether in the form of (partial) exclusions from taxable income or reduced rates, should be treated with caution. From another angle, preferential regimes for the consumption of environmentally damaging goods should be imputed more decisively if the EU wants to be taken seriously in the commitment to curb emissions. It also happens that, over time, the application of systems that had not been thought of as preferential mechanisms leads to unjustified differences in tax treatment. For example, states' tax administrations should be fostered to keep their databases up-to-date, in particular in the area of real estate. Monitoring could also focus on states' positive experiences, fostering a sharing of best practices regarding the design of efficient incentives, for example, in the field of education and training as well as health and social protection or employment policies (such as earned-income tax credits).

Finally, as other scholars have already forcefully advocated, ${ }^{7}$ greater uniformity of taxpayer rights should be achieved at the international and EU scales. The intensification of administrative cooperation and exchange of tax information must go jointly with the effective guarantee of taxpayers' rights in cross-border and domestic situations. This is, of course, the case of right to privacy and data protection according to which the taxpayer should have the right at any time to be able to verify and possibly rectify the information about him of which the different tax administrations would be in possession. It is also believed that there is the right to a fair trial and an effective remedy that allows a taxpayer who finds himself in a harmful situation due to the lack of coordination by tax administrations of different Member States. That individual should be able to provide an effective dispute resolution mechanism and be able to be heard. Other rights such as the principle of equality, legality, property, or the right to private and family life have been recognized for taxpayers in the constitutional tradition of the states and in the case law of EU and international courts, particularly the European Court of justice and the European Court of Human rights. At the EU level, the European Commission has announced initiatives in this area for this year. ${ }^{8}$

In this perspective, it is a good omen that some of the contributions published in this issue deal with personal income tax. It is hopeful that it will announce a renewed interest for an area that has been shadowed for too long by other, in particular corporate income tax and - who knows? - could offer new perspectives on some of the conundrums faced by the international tax community such as fairness, sustainability, and legal certainty.

Edoardo Traversa

Professor of Tax Law at UCLouvain.

Email: edoardo.traversa@uclouvain.be.

\section{Notes}

European Commission, Communication of 15 July 2020 on Tax Good Governance in the EU and Beyond, COM(2020) 313 (15 July 2020 ), at 5.

European Commission, Communication of 15 July 2020 on an Action Plan for Fair and Simple Taxation Supporting the Recovery Strategy, COM (2020) 312 (15 July 2020), at 10.

See e.g., J. Kokott, P. Pistone \& P. Merkouris, ILA Study Group on International Tax Law: The Protection of Taxpayers' Rights in International Law - Preliminary Report 2020 (Contributor to certain Sections). (ILA 2020).

8 European Commission, supra n. 6, at 10. 